\title{
Imaginarios de amistad, autoría y deseo: la figura de la escritora en la prensa argentina de 1880
}

María Vicens

Universidad de Buenos Aires/Conicet

\begin{abstract}
Resumen

Palabras clave:
Escritoras
Sororidad
Prensa
Emociones
Frivolidad
Autoría
\end{abstract}

Este artículo analiza el imaginario que se construyó en torno a la figura de la escritora en la prensa argentina para mujeres de 1880 y cómo este mundo de afectos idealizados y feminizados muestra sus fisuras en las secciones "subalternas" de esas publicaciones. En sus columnas de moda, de crónica social y misceláneas, circulan emociones y gestualidades anti-normativas para el "deber ser" femenino de la época (gritos, enojos, reclamos, pero, también, deseos y ambiciones) que operan como doblez de esa comunidad afectiva, abriendo el espacio de la prensa a nuevas voces y tonos femeninos.

\begin{abstract}
This article analyses the imaginary that was built around the figure of the woman writer in the argentine female magazines of 1880 y how this universe of idealized and feminized affections shows its fissures in the minor sections of these publications. In their fashion columns, social chronicles and miscellaneous circulate anti-normative emotions and gestures (screams, anger, claims, but also desires and ambitions) that dispute the feminine model of this period and operate as a crease of that affective community, opening the space of the press to new voices and feminine tones.
\end{abstract}

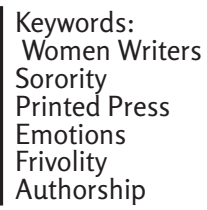

En 1892, poco después de la muerte de su madre, Julio Sandoval publica en Buenos Aires Veladas literarias de Lima, primer volumen de una serie que proyectaba editar los textos leídos en las célebres reuniones organizadas por Juana Manuela Gorriti 
en la capital peruana entre 1876 y 1877 . Preparado por la escritora en los últimos años de su vida, este libro entrecruza su aparición con la pérdida de su autora y se carga de emociones prestigiosas para el imaginario romántico decimonónico (como la melancolía y la nostalgia), en franco declive ante el clima modernizador de la Buenos Aires finisecular. ${ }^{1}$ Así lo expresan los prefacios que el hijo solicita a dos amigos de su madre, ya que, si Ricardo Palma excusa su renuencia a prologar el libro en la incapacidad de controlar sus sentimientos frente a la pérdida de sus amigxs — "el libro que a la vista tengo melancoliza mi ánimo con la tristeza de las tumbas", señala (Gorriti, 2016: 37) - , Pastor Obligado se respaldará en esa misma nostalgia ante el pasado para entronizarla como la gran escritora americana. Para ello, Obligado no tomará como punto de partida la célebre biografía de Gorriti, regada de exilios, guerras y próceres americanos, sino que, por el contrario, elegirá una escena doméstica, también cruzada por la intensidad emocional que provoca la muerte y protagonizada por dos mujeres. Detalla Obligado:

Apenas llegada a esta ciudad la señora Gorriti, y sabedora de que la señora Manso hallábase postrada en el lecho del que ya no habría de levantarse, trasladóse a la casa de la que expiraba, y con profunda emoción se inclinó diciéndole: “Permítame, al pedirle su amistad, besar la mano de mi maestra y mi colega, pues que, aun de muy lejos, he seguido sus huellas y estudiado en sus libros".

Así, al borde de una tumba entreabierta, se saludaron y despidieron para siempre estas dos famosas literatas americanas que, partiendo de tan distintos puntos, vinieron a encontrarse, por un momento, en la hora de separarse por una eternidad. (2016: 40)

El cuadro bien podría confundirse con el de una clásica novela sentimental decimonónica en su carácter extremo y declamatorio. La intimidad del vínculo -ilustrada en la pose de Gorriti a los pies de la cama-, la inminencia de la muerte, las palabras y los gestos de cariño exacerban la emoción de un encuentro que enmascara en su sentimentalismo la dimensión política de lo que se narra: el gesto de legitimación recíproca entre dos mujeres de letras, dos de las autoras más importantes de la Argentina del siglo XIX, que adquiere carácter público al ser evocado por el amigo escritor. Como en el caso de la carta de Palma, inundada de una emoción que obtura cualquier posibilidad de juicio crítico - “el corazón no es literato, ni sabe de estética: no raciocina ni discute, siente y ama... porque sí", sostiene (ibídem: 35) -, la muerte de Manso resuena en la más reciente de la propia Gorriti y tiñe de melancolía un pasado no tan lejano en el cual las mujeres, en tanto escritoras, tienen un lugar delimitado, pero propio: el de los sentimientos y la domesticidad.

En este punto, la fecha del episodio elegido por Obligado (Manso muere en abril de 1875) también se vuelve significativa para analizar el proceso de consolidación de la autoría femenina en el imaginario local, no solo porque es el año en el que Gorriti regresa al país tras décadas de exilio, sino también (y sobre todo), porque es hacia finales de los setenta cuando la prensa para mujeres empieza a crecer y diversificarse a través de proyectos como La Ondina del Plata (1875-1880), La Alborada del Plata (1877-1878/1880) y ElÁlbum del Hogar (1878-1887), y es en estas publicaciones donde

1 Tanto Graciela Batticuore como Francesca Denegri han destacado la influencia del romanticismo americano en el proceso de legitimación de las escritoras argentinas y peruanas durante este período, ya sea por el interés de los letrados en la figura de la lectora y el rol que adjudican a las mujeres en tanto madres republicanas en la construcción de las nuevas naciones americanas, como ha analizado Batticuore (2005), o por el efecto de feminización cultural que produce el romanticismo al enfocar su estética en el mundo de las emociones, como señala Denegri (2004). Ambos aspectos se observan con particular intensidad en las Veladas Literarias que refuncionalizaron las tradicionales tertulias domésticas en eventos de carácter público reseñados en la prensa y donde las mujeres tuvieron un rol protagónico (Batticuore, 1999). 
se visibiliza la figura de la escritora y donde las jóvenes con aspiraciones literarias dan sus primeros pasos. ${ }^{2}$ Pensados para interpelar al público femenino en expansión, estos periódicos reproducen y construyen en tanto "tecnologías de género", es decir, artefactos culturales destinados a promover y naturalizar determinados rasgos, poses y modos de "lo femenino" (De Lauretis, 1987), códigos afectivos e imágenes normativas vinculadas a los roles sexo-genéricos de la época, estableciendo una relación jerárquica entre estos y las emociones asociadas a ellos. Así, la caridad, la sensibilidad y el cariño serán asignados al "deber ser" femenino (en oposición a la osadía, la vehemencia y la ira asociadas con la masculinidad) entretejiendo una matriz modélica, a partir de figuras como las del ángel del hogar y la madre republicana, en base a las cuales estos periódicos asumen una función pedagógica y prescriptiva para las nuevas lectoras que empiezan a asomar como un público concreto.

Este universo discursivo en construcción encontraría en la figura de la escritora una de sus protagonistas, no solo porque las mujeres letradas a menudo colaboran con sus propios ensayos morales en el despliegue de la vocación normativa de estas publicaciones, sino también, porque a medida que se afirmen estos periódicos y nuevas colaboradoras se sumen a sus páginas, la autoría femenina empezará a perfilarse como un tema de debate y reflotará miedos y fantasmas que deberán ser conjurados a partir de ejemplos modélicos. ${ }^{3}$ Si bien una lectura detallada de periódicos como La Ondina de Plata, La Alborada del Plata y El Álbum del Hogar revela cierta diversidad de posturas en relación con la "agenda temática femenina" de la época, centrada en la educación, la emancipación y la profesionalización femeninas, hay premisas que nunca están en discusión, como la maternidad, la división de los roles de género en las esferas pública y privada y la asociación de estas funciones, en el caso de las mujeres, con el universo afectivo de la modestia, la sensibilidad y la virtud. Estas premisas son las que se proyectarán en los retratos de escritoras que promueven los periódicos para mujeres del período, con la "corrección" y el "reencuadramiento" incluso de sus propias biografías.

\section{Emociones ejemplares}

Una de las novedades más importantes de la prensa para mujeres de los ochenta fue la participación de las lectoras, devenidas en colaboradoras, en sus páginas y la exhibición progresiva de sus ambiciones autorales, como demuestran, por ejemplo, las trayectorias de Josefina Pelliza de Sagasta, Lola Larrosa y Raymunda Torres y Quiroga, quienes dieron sus primeros pasos literarios remitiendo poemas breves y charadas a estos periódicos y ganaron espacio en sus páginas a partir de la publicación de sus ensayos morales y novelas, así como de sus intervenciones polémicas y secciones misceláneas. ${ }^{4}$ Esta avanzada comenzaría a producir reticencias en el espacio de 2 Todos estos periódicos se dirigieron al público femenino pero, mientras que La Ondina del Plata, dirigida por Luis Telmo Pinto, se centró inicialmente en un discurso más tradicional que, con el tiempo, se fue flexibilizando gracias a la dinámica relación que entabló con sus lectoras, El Álbum del Hogar, de Gervasio Méndez, propuso un tono joco-satírico más centrado en lo literario, a partir del cual proliferaron diversas polémicas y seudónimos masculinos y femeninos, y La Alborada del Plata, fundado por Juana Manuela Gorriti, desplegó una veta transnacional, al defender una literatura de corte americanista y aprovechar las amistades que Gorriti tenía en Lima y en otros países del Cono Sur.

3 Francine Masiello (1997) y Graciela Batticuore (2005) han reconstruido los primeros debates vinculados con la figura de la mujer publicista, a raíz de la publicación de La Aljaba (1830), La Camelia (1852) y Álbum de Señoritas (1854), siempre iniciados por publicistas hombres y enfocados en cuestionar la habilidad de las mujeres para dirigirse al público. A excepción de Manso, quien adjudicó las causas del cierre de Álbum de Señoritas a la falta de suscriptoras, estos ataques marcaron el punto final a las breves vidas de La Aljaba y La Camelia.

4 Dentro del grupo de escritoras que comienza a escribir en la prensa para mujeres de este período, Josefina Pelliza de Sagasta y Lola Larrosa fueron quienes lograron publicar varios libros - novelas, en su mayoría-, además de secundar a Gorriti como codirectoras de La Alborada del Plata en diferentes 
estos periódicos y el problema, ya no de ser escritora, sino de qué tipo de escritora ser se convertiría en una cuestión crucial. Y para pautar comportamientos y propuestas literarias, ¿qué mejor que las vidas de las propias escritoras y amigas? Los retratos de figuras ya reconocidas como Manso, Gorriti y Eduarda Mansilla se presentan a partir de rasgos e imágenes ejemplares que reinterpretan sus vidas en clave modélica. ${ }^{5}$ Un ejemplo paradigmático es la semblanza de Juana Manso que publica La Ondina del Plata a raíz de su muerte en 1875 , firmada por su propio director, Luis Telmo Pintos. Lejos del perfil combativo que la escritora había mostrado en sus escritos e iniciativas, el foco de atención en el texto de Pintos serán las emociones asociadas a la figura de la madre republicana, al destacar sus aportes como "austero apóstol de la enseñanza", su "corazón sensible y sentimientos elevados" y su abnegación durante el último período de su vida, ya que, según Pintos: "Sin valor para enrostrar la mentira y la calumnia lloró amargamente y sus días fueron un lento martirio" (1875a: 145).

La intención de homenajear a quien había sido una referente en el campo de la prensa para mujeres y un respaldo en los inicios de La Ondina del Plata se destaca, antes que nada, por las elecciones discursivas e ideológicas del propio Pintos, quien retrata a la publicista como una víctima abnegada de sus circunstancias, más que como una polemista conocida y una innovadora en el campo cultural gracias a prácticas de profesionalización como las conferencias, la redacción de manuales y la dirección de periódicos como Álbum de Señoritas y El Monitor de la Educación Común. La reseña laudatoria hace a un lado el perfil de la escritora romántica, politizada e independiente (Zucotti, 1998), para subrayar el de la madre austera, cristiana y entregada al magisterio. Todo, aunque parezca paradójico, para recordar a Manso con la mayor de las honras.

El mismo gesto se repetirá a la hora de retratar a otra de las aliadas de Pintos, la mismísima Juana Manuela Gorriti, cuya vida atravesada de escándalos (especialmente, su separación de Manuel Isidoro Belzú y los hijos que tuvo por fuera de ese matrimonio) suscitaba, como ha señalado Graciela Batticuore (2005) fascinación y rechazo al mismo tiempo. Pintos capitaliza la atención que suscita la llegada de Gorriti a Buenos Aires a principios de 1875, ofreciéndole las páginas de La Ondina del Plata como espacio de promoción, a la par que opta por adaptar su impronta autoral a una imagen más bien tradicional:

La señora doña Juana Manuela Gorriti no pertenece como Jorje Sand á una escuela filosófica, ni como esta tiene los refinamientos del arte y del estilo; pero en cambio posee el sentimiento de lo bello y de lo bueno que distinguió á la autora de Margarita ó los dos amores, la malograda Sofía Gay, Madama de Girardin. Sin la correccion de lenguaje de Fernan Caballero, tiene como esta afamada escritora española, el amor á la verdad, á la sencillez, y sin ser realista describe fielmente la naturaleza, animándola con los tintes del ideal. La escritora no olvida á la mujer; la literata recuerda siempre que es cristiana; y por eso sus novelas y sus crónicas son recreativas, morales, y pueden sin recelo ponerse en manos de las vírjenes y entrar por la puerta principal en el hogar de la familia que mas dada sea á la práctica de la virtud. (1875b: 53)

épocas. Por otro lado, tanto Pelliza de Sagasta como Torres y Quiroga (conocida también por uno de sus seudónimos, Matilde Elena Wili, con el que publicaba cuentos de terror fantásticos) escribieron columnas de crónica social joco-satíricas en El Álbum del Hogar y entablaron varias polémicas entre sí y con María Eugenia Echenique, aspecto que se retomará más adelante.

5 Estos retratos ejemplares se pueden relacionar con las galerías de mujeres ilustres, sección clásica de la prensa femenina europea, desde finales del siglo XVIII en adelante, que busca, como han analizado Mónica Bolufer Peluga (2000: 181-224) para el caso español y Linda Peterson (2009) en el contexto inglés, disipar las tensiones provocadas por la mayor participación de las mujeres en la esfera pública, creando "versiones aceptables" de autoría femenina centradas en la belleza, la feminidad y la domesticidad de sus protagonistas, que a menudo contrastan u omiten los aspecto más escandalosos o rebeldes de esas biografías. 
Además de evitar los famosos rasgos heroicos y arrojados de Gorriti (su liderazgo en la revuelta popular que había desencadenado el asesinato de Belzú en La Paz, por ejemplo), el texto suaviza su perfil, convirtiendo también sus textos, ya no en romances de mujeres aventureras y heroínas que se abren paso en un mundo lleno de violencia y peligros, como se observa en los relatos de Sueños y realidades (1865) y Panoramas de la vida (1876) -especialmente en Peregrinaciones de una alma triste, incluida en este último libro-, sino en lecturas sanas y morales, "recomendables". La caracterización plantea en este punto dos modelos contrapuestos para las escritoras más jóvenes: por un lado, asoma el perfil escandaloso y seductor de George Sand, con quien a menudo era comparada la propia Gorriti, y, por otro, el de la modestia de Fernán Caballero, seudónimo de Cecilia Böhl. Estas dos célebres novelistas europeas sugieren mitos autorales casi opuestos que se reflejan en el uso diferencial del seudónimo masculino: la francesa apasionada que lucha por el mismo reconocimiento de sus colegas hombres, reforzando el reclamo con la provocación del traje y el seudónimo masculinos, en oposición a la española correcta quien, en lugar de desafiar con su alter ego masculino, busca protegerse con él. Gorriti es identificada con este segundo perfil, a pesar de que su biografía, ampliamente conocida en esa época, apuntaba en el sentido contrario.

Este posicionamiento se va a repetir sistemáticamente en los periódicos del período 1870-1880. Frente a la aparición de un público femenino concreto al que se debe cooptar, estimular y guiar de manera simultánea, tanto la figura de Gorriti como la referencia a sus textos se vuelven, ante todo, ejemplares: se la compara con Fernán Caballero o Madame de Staël y se resaltan la sencillez y la virtud de sus relatos, en un gesto de normativización que busca ayudar a la escritora amiga mediante la promoción de su lectura.

Lejos de cuestionar esta visión ejemplar de la autoría femenina, las escritoras que participan de estos periódicos se apropiaron de esos códigos afectivos para formar una "comunidad emocional", en términos de Barbara Rosenwein (2006) en la que, sin rechazar la pertenencia de los hombres (la amistad con Palma, por ejemplo, es central en el caso de Gorriti y sus colegas peruanas), privilegian las figuras femeninas a la hora de proponer escenas de afirmación autoral donde la amistad está planteada en términos sexo-genéricos (se identifican como "hermanas en las letras") y adquiere ciertos rasgos recurrentes. De hecho, la escena referida por Obligado al comienzo de este trabajo, a fuerza de repetirse, se revela como un verdadero tópico en la configuración de la autoría femenina de finales del siglo XIX, que las propias escritoras utilizarán para retratarse y retratar a sus colegas: la escenificación de estos encuentros en el ámbito doméstico en oposición a espacios típicos de legitimación literaria (los ateneos y las universidades, por ejemplo), la alusión a una confianza espontánea y sin mediaciones ni reparos, así como el cariño expresado a partir del contacto físico del abrazo se repiten una y otra vez en las escenas de consagración escritas o protagonizadas por mujeres, constituyendo en esa recurrencia una verdadera retórica sororal en la que las escritoras del período se apoyaron para reconocerse pública y recíprocamente como autoras. ${ }^{6}$

Tanto la repetición como el carácter idealizado de estas escenas dan cuenta de la naturaleza prototípica de este imaginario compartido: así como las revistas para mujeres y otras tecnologías de género (manuales de conducta, cancioneros, publicidades, obras literarias) modelan las relaciones afectivas y los roles de género de la época, la retórica sororal ofrece a las escritoras una matriz discursiva para intervenir en la esfera pública, expresar sus ambiciones autorales y trazar una genealogía literaria en

6 He analizado la configuración específica de esta retórica en el contexto transnacional de finales del siglo XIX en el artículo "Por una tradición propia: genealogías y legitimación en las escritoras transhispánicas de entresiglos” (2019: 371-395). 
la cual escudarse ante las clásicas acusaciones de soberbia y falta de preparación con las que históricamente se atacó a las mujeres letradas. Hay, además, otro elemento que demuestra el carácter retórico de estas escenas: en sus diarios y correspondencia privada (al menos, en las escasas fuentes que han logrado sobrevivir a la desidia y a la falta de interés a la hora de preservar estos archivos) las escritoras muestran los desacuerdos, las tensiones y las competencias que se despliegan de la mano de la autoría, y cómo los vínculos entre ellas y con el campo letrado en general se juegan en los dobleces y claroscuros que plantea el mundo de la intimidad ante la lógica y las políticas de amistad de la esfera pública.

Graciela Batticuore (2005) y Ana Peluffo (2005) han destacado las tensiones en la configuración de estos vínculos, aspecto que puede ser analizado especialmente en Lo intimo (1898), el diario que Gorriti dejó para ser publicado de manera póstuma. Los comentarios indignados de la escritora sobre Mercedes Cabello de Carbonera por su giro hacia el naturalismo, las dificultades que refiere cuando quiere hacer amistad con Eduarda Mansilla o su intención de acelerar los plazos de Cocina ecléctica para evitar que Emilia Pardo Bazán publique primero su libro de cocina española, entre otros episodios referidos en su diario, demuestran, como señala Peluffo, un "clima de armonía falsa" (2005: 151) que puede rastrearse en estas comunidades sororales y los diversos modos en que las escritoras encubrían, a través de sus poses y discursos centrados en la afectividad femenina, "no solamente el rechazo y la ambivalencia frente a mujeres de otras razas y clases, sino también, en el caso de las mujeres de la misma clase social, la competencia y la sororofobia" (ibídem: 151).

A estas tensiones vinculadas con el ámbito de la escritura privada, me interesa sumar otra dimensión que emerge en el espacio público, más precisamente, en las páginas de la prensa. Porque, si los modelos normativos promovidos por estos periódicos y sus avances en relación con la educación y la emancipación femeninas han sido, por lo general, los ejes de análisis de las investigaciones sobre la prensa femenina local (Auza, 1988; Masiello, 1994; Frederick, 1998), menos atención ha recibido, en cambio, un segundo rasgo igual de importante en este tipo de proyectos: el imperativo de entretener e, incluso, de hacer reír, para atraer a ese público femenino en ciernes, a partir de la inclusión de secciones de crónica social, modas y misceláneas destinadas a la frivolidad y la diversión. Si bien estas secciones no son exclusivas de la prensa para mujeres -Víctor Goldgel ha analizado cómo operan estos "espacios frívolos del periodismo" (2013: 104) en diversos diarios latinoamericanos durante la primera mitad del siglo-, sí presentan efectos específicos en estos periódicos, no solo porque el mundo de la moda, la elegancia y lo bello ha sido tradicionalmente asociado con las mujeres, sino más bien por el tipo de relación que estas secciones establecen con las "zonas serias" de esas mismas publicaciones. Barbara Rosenwein (2006) y Sarah Ahmed (2004) han señalado cómo la cohesión afectiva de ciertos grupos y comunidades se sostienen sobre la valoración de determinados sentimientos y la consecuente creación de enemigos internos o externos en los que se "depositan" las emociones negativas. Sin embargo, la inclusión de tonos jocosos y picarescos en estas secciones de crónicas y misceláneas, en la libertad que ofrece lo trivial ante el imperativo de instruir, desarticulan la naturalización de esas relaciones e introducen afectos y emociones heteronormativas para ese mundo femenino ficcionalizado.

En su vocación por entretener, los periódicos para mujeres apelan en estas secciones a tonos que exceden ese "deber ser" femenino que promueven en sus "zonas serias" y, a partir del uso de seudónimos, de la sátira y de la ficcionalización, perturban los parámetros afectivos de la época. Así, exhiben tanto el carácter codificado de estas representaciones, como los bordes más "problemáticos" de la creciente participación de las mujeres en la república de las letras. 


\section{Cronistas indignadas}

En un salón de una casa porteña de finales de la década de 1870 se reúne un grupo de mujeres. ¿El objetivo? Intercambiar información sobre las fiestas, modas y chismes de la semana, con Carmen, responsable de la sección "Correrías y Modas" de El Álbum del Hogar, como líder que administra la charla y hace sonar una campanilla cada vez que se desmadra. Este elemento también le sirve para trazar todo tipo de analogías con la labor parlamentaria de la época: como sus congresistas, las integrantes de esa pequeña república femenina tampoco logran avanzar demasiado en sus compromisos; son desordenadas y poco productivas. Su salón, repite una y otra vez Carmen, no se distingue demasiado de los avatares legislativos contemporáneos, por más que sus amigas tengan intenciones mucho más loables que las de los políticos de la época. La excusa para reunirse es la moda, pero la charla sistemáticamente derivará hacia otras zonas de la realidad contemporánea (desde los matrimonios por conveniencia, la infidelidad y el carnaval, hasta los derechos políticos de las mujeres y los escándalos del gobierno) a tal punto que por momentos se llega a dudar de qué está al servicio de qué: si la moda es una excusa para referirse a través de la ficción y el humor a los temas "candentes" de la época o al revés. Lo que sí está claro es que, en esa sección aparentemente inocua por la frivolidad de sus temas, se habla de mucho más que de las tendencias de la temporada y de chismes, y que esas voces están construidas sobre la base de un discurso jocoso y picaresco, ya que se proponen como una crítica a las costumbres de ese tiempo en clave humorística y con un objetivo de reforma social. ${ }^{7}$

Pero, a diferencia de otras columnas de crónica social o secciones satíricas, muy comunes en la prensa decimonónica, "Correrías y Modas" presenta desde un principio ciertas particularidades que van a desestabilizar la retórica sororal que circula en los periódicos para mujeres de los ochenta, ya que no solo propone un colectivo de voces femeninas que fisuran las poses modélicas con sus voceos, sus chismes y sus referencias al mundo de la política, sino que estas amistades femeninas aparecen atravesadas por un nuevo espacio público como es el de las grandes tiendas, esos lugares novedosos y modernos de "lujo democratizado", como los define Bill Lancaster (1995: 31), donde emergen tensiones de clase (Hallstead, 2006) y se alteran las relaciones del género y los códigos afectivos de la época, como ya aparece planteado en su primera entrega:

-Anoche fui á dar unas vueltas por la calle de la Florida, á la que frecuenta hoy muy poco nuestra sociedad con motivo de la temperatura nada agradable y llegué hasta la Ciudad de Lóndres. [...] En la tienda había algunas compradoras y un regular número de esas bestias negras de los dependientes que piden y rechazan y vuelven y revuelven y se agitan y charlan hasta por los codos y concluyen por tomar el portante sin comprar nada.

-Es cierto y cuando se enojan, concluyen por amenazar al tendero con retirarle su protección...

- ¡Sí, pero en cambio, cuando las tales embromadoras son bonitas, lo cual sucede muy pocas veces, los mozos de las tiendas se vengan amenizando con una cuchufleta las explicaciones sobre generos!

- ¿Has visto, ché?... ¡ Estos mozos de tienda son deliciosos! ¡Me gustan todos en general. Algunos de ellos se mueren por darnos la mano y oprimirla suavemente entre las suyas; á otros les da la chaveta por hacerse los románticos y dale con

7 Para un análisis detallado del desarrollo de la prensa satírica en la Argentina, sus recursos y su vinculación con el público, ver Román, Claudia, Prensa, política y cultura visual. El Mosquito (Buenos Aires 1863-1893) (2017). 
hablar de Grazziella y de los amantes de Teruel y de la María de Isaacs y de los pobrecitos inmigrantes que se suicidaron en Belgrano! (1878a: 5)

En la confianza del "entre-nos" femenino y la protección de las voces ficcionalizadas y la seudonimia irrumpen nuevos espacios, imágenes y comportamientos que resquebrajan el "deber ser" femenino promovido por el mismo periódico y desorganizan los códigos afectivos de la época: esos espacios públicos y urbanos que inauguran las tiendas departamentales, donde se estimula el deseo por los bienes materiales sin culpas ni tapujos, son la oportunidad para introducir figuras disruptivas de los modelos de feminidad que promueven en sus páginas, como las consumidoras sin dinero (ni estirpe) que circulan libremente por esos ámbitos y se mezclan con la elite, o aquellos trabajadores que, en las pasiones irónicamente aludidas por estas cronistas y en el amaneramiento de su gestualidad romántica remiten a un universo homo-afectivo que se repetirá a menudo en la sección al aludir a las "poses almibaradas de los dandys" (1879g: 235) o a "los dandys afeminados que emplean en atarse la corbata un tiempo que podrían utilizar aprendiendo a poner su apellido con ortografía" (1879h: 322 ). Es en este mundo de frivolidades, pasiones desatadas y emociones desordenadas donde el matrimonio se revela como una farsa - "Decididamente, hoy con más urgencia que nunca hay que dirijir la voz de alarma al sexo débil en general, porque las especulaciones matrimoniales van asumiendo proporciones aterradoras y disfrazándose con el cínico antifaz del más refinado sentimentalismo", sostiene Carmen (1878c: 54) - y las mujeres exhiben emociones que alteran el imaginario sororal.

En el centro del juego que propone "Correrías y Modas", a través del tono y la lógica parlamentarias, se encuentran los debates sobre los derechos políticos de las mujeres y la inclusión de emociones antinormativas como la protesta, el enojo, la indignación y el "mal humor" en esas voces femeninas, ya sea que reclamen por los errores de tipeo del periódico - "quiero protestar contra el inícuo proceder de los cajistas y de los correctores del Album del Hogar, que han hecho salir plagado de errores la revista del Domingo pasado. La cosa me puso tan de mal humor que casi me cuesta una enfermedad", exclama Sara, una de las cronistas (1878b: 22) - , la discontinuidad del folletín favorito del momento publicado en El PuebloArgentino (s/f: 23) o la hipocresía de los bailes de caridad donde "una minoría se divierte para atenuar en algo la miseria y el llanto de la mayoría" (1878d: 69), al punto de anunciar que llegará un día en que se reconozcan los esfuerzos de las cronistas y se declare la "jempantalonización de las mujeres!" (1878b: 22).

En sus alusiones breves y filosas, así como en la mostración de esos tonos malhumorados y quejosos, las jóvenes cronistas de "Correrías y Modas" se vinculan con el análisis que Ahmed propone respecto de la figura de la "feminista aguafiestas" en La promesa de la felicidad y cómo en la cultura occidental "cualquier desviación de los roles de género, entendidos en términos de que es preciso entrenar a las mujeres para hacer felices a los hombres, constituye una desviación de la felicidad común" (2019: 131).

En este mundo cruzado por la ficcionalización y la sátira, las categorías se vuelven inestables, duales, incluso la de la figura de la escritora. Así, bien puede aprobarse una "moción para que nos pongamos todas de pie y hagamos votos por el feliz viaje de la simpática autora de Sueños y Realidades" (1878b: 23) que es aprobada "por aclamación" (ibídem: 23) o comparar a las escritoras con la superficialidad de una moda más en una sociedad en la que cualquier actividad humana se ha vuelto frívola. Comenta Carmen:

¿Quien de nosotras ignora los rumbos de la moda en estos tiempos de modestia en que todo el mundo aspira, por lo menos, á ser una notabilidad? Los hombres y las mugeres se visten de sabios, de literatos, de políticos, de emancipistas, de escritoras, de poetisas, etc. —sin necesidad de pedir consejo á nadie, pero consultando siempre las inclinaciones dominantes de la época. (1879g: 234) 
A su manera, estas voces femeninas se integran en sus reclamos, enojos y denuncias en esas "genealogías de la infelicidad" señaladas por Ahmed que entretejen, en el revés de la retórica sororal, su propia red de mujeres indignadas quienes, como señala Peluffo, "estetizan estas emociones en nombre de un incipiente feminismo" (2016: 29). Sin los posicionamientos de avanzada que Peluffo ha analizado en los casos de Flora Tristán y Gertrudis Gómez de Avellaneda o, en el contexto local, en una escritora como Juana Manso, estas secciones, sin embargo, abren el juego en el mundo de la prensa para mujeres a otras voces y emociones femeninas, de las que las escritoras noveles de la época también se harán eco y aprovecharán en su beneficio. Por ejemplo, es en este ámbito donde se comentará la polémica que Josefina Pelliza de Sagasta entable en las mismas páginas de El Álbum del Hogar con Antonio Argerich en torno a la figura de la mujer escritora, en clave lúdica, ya que las colaboradoras de "Correrías y Modas" protestan del siguiente modo:

- Se trata de levantar el ultraje gratuito inferido a la dignidad de la mujer que se sacrifica generosamente por el brillo de la literatura, alternando las pesadas ocupaciones del hogar doméstico y de la vida en familia con los dulces y poéticos placeres de la inteligencia; se trata de protestar contra la conducta de un hombre audaz y descomedido que ha pedido... nada ménos... ique le sirvan una literata!

- iEs verdad! —-prorrumpió la asamblea casi en coro-El señor Da Freito nos ha ofendido gravemente al reírse de las mujeres literatas; es necesario escarmentarle una vez por todas, para que en adelante aprenda á proceder como se debe. $(1878 \mathrm{e}: 180)^{8}$

Ese reclamo colectivo y público contra los ataques masculinos, en su tono jocoso, expresa uno de los mayores fantasmas que circulan en las páginas de la prensa de esos años: la politización femenina y el reclamo de mayores derechos, reivindicación que esas mismas colaboradoras rechazan como "una moda más". En este marco, la propia Carmen intervendrá ante sus colegas cronistas para "poner orden":

Una novedad vieja, sostenida con todo el entusiasmo de las malas causas, viene á agregarse á las anteriores: se pretende rejuvenecer á un anciano decrépito, resucitando el problema que yace aprisionado por la planta de la reprobación universal, se canta en todos los tonos la conveniencia de investir á la mujer con derechos políticos. Lo paso por alto, mirándolo como producto de algun literato desocupado que sueña con la presidencia de la República y que piensa aumentar la lista de sufragios á su favor con la opinion de su esposa y de la cocinera de su casa. (1879f: 210)

Estas primeras reacciones a finales de los setenta preanuncian sin duda la ansiedad que Peluffo ha detectado en los representantes del modernismo finisecular en relación con lo que la investigadora llama "la invasión femenina de la república de las letras" (2016: 85) pero, a diferencia de las críticas de Martí hacia Gertrudis Gómez de Avellaneda o el rechazo de Darío de esa monstruosa "sisterhood of scribiling women" (ibídem: 85), tanto el dinamismo propio de la prensa como el tono satírico de este tipo de secciones relativizan los ataques y abren el juego a diversas voces y posturas. Porque, además de hacerse eco de las secciones serias del El Álbum del Hogar, las colaboradoras de "Correrías y Modas" dialogan con otras columnas que presentan un tono similar y las convocan a pronunciarse sobre temas políticos muy debatidos en esos años como la reforma del Código Civil. En "Cortes y Recortes", por ejemplo, columna firmada por Tijerita, se señala en relación con la reforma del Código Civil a la que Carmen y sus amigas sostienen oponerse horrorizadas: 
¿Qué tal, Cármen, con la condena? ¡Ah! ¡si nosotras, las mujeres, fuéramos jueces cuántas sentencias no decretaríamos!... jay! suspiro... pero eso no lo veremos -los hombres nos temen y hacen leyes buenas para ellos-es decir: la ley del embudo. Traslado á Raimunda, la valiente defensora de la emancipación. (1878: 334)

La intervención de Tijerita en este punto es una atractiva provocación, ya que exhibe los matices y posiciones específicos que las escritoras de la época asumen frente a temas polémicos como los derechos políticos y civiles de las mujeres. Opositora de la emancipación femenina, Josefina Pelliza de Sagasta recurre a su seudónimo para cuestionar las posiciones de su colega en relación con la reforma del Código Civil que ella sí defiende, especialmente en lo que se refiere al derecho de las mujeres a administrar sus bienes y a la patria potestad de sus hijxs (Barrancos, 2007; Crespo, 2017: 9-47). No será tampoco la primera ni la última vez que Pelliza de Sagasta recurra a los tonos joco-satíricos y a los códigos lúdicos que ofrecen la seudonimia y este tipo de secciones frívolas para quebrar la retórica sororal y la pose de modestia a las que la obligaba el deber ser femenino de la época. Por el contrario, tanto ella como Raymunda Torres y Quiroga utilizan estas secciones como un canal alternativo (una especie de lado B de sus propias construcciones autorales) que comenta, critica y polemiza a través de esas voces los debates que ellas mismas protagonizan en las "zonas serias" del periódico de Méndez y de otras publicaciones como La Alborada del Plata.

Florencia Buret (2017) ha reconstruido en detalle los intercambios entre ambas escritoras y cómo estos debates implicaron un reposicionamiento autoral en el caso de Torres y Quiroga a través del seudónimo de Matilde Elena Wuili, ${ }^{9}$ pero lo que me interesa destacar en este punto es el modo en que la proliferación de estas secciones frívolas en periódicos como La Alborada del Plata y El Álbum del Hogar desestabilizan su propia matriz normativa y filtran en esas voces que asumen abiertamente el juego de la ficcionalización tonos e idea que fisuran el ideal femenino de la época. Si Pelliza de Sagasta es cuidadosa en preservar las formas y los límites de sus reclamos a la hora de, por un lado, reivindicar la figura de la escritora y, por otro, pronunciarse en contra de la emancipación de la mujer, a través de las diversas polémicas que protagoniza en la prensa con colegas como Jorge Argerich, María Eugenia Echenique y Torres y Quiroga, el "como si" de la sátira le permitirá ensayar otros tonos, considerados impropios para una escritora con cierto renombre como el siguiente comentario dirigido a Torres y Quiroga, lanzado desde la sección de "Variedades" que firma con el seudónimo Figarilla en La Alborada del Plata: "Vamos a darle un consejo - ¿nos lo permite? De todos modos oiga - déjese de emancipación porque entusiasmándose tanto puede perder el... asunto y dejar a la mujer argentina sin su más decidida defensa" (1878: 143-144).

Sin presentar un discurso unívoco, estos espacios cruzados por la ficcionalización y la sátira abren el juego y desestabilizan las categorías sexo-genéricas, en un momento de incipiente modernización del campo cultural y es en este marco que no solo exhiben los temores del campo letrado ante la democratización de la cultura, sino que también perturban los límites establecidos para los códigos afectivos de la época y se permiten jugar con ellos, al menos en el mundo pasajero de la prensa. Porque es en la prensa también donde un poeta como Bernabé Demaría puede liberar sus deseos literarios 9 Carlos Abraham (2012) y Florencia Buret (2017) han analizado los diversos seudónimos asumidos por Torres y Quiroga en la prensa para mujeres y cómo, a partir de estas firmas, la joven exhibe diversas facetas autorales, alternando posiciones emancipistas cuando firma como Torres y Quiroga y posturas más tradicionales, al asumir seudónimos como Matilde Elena Wuili y Luciérnaga. De hecho, Buret ha reconstruido un intenso intercambio entre Torres y Quiroga y Pelliza de Sagasta en torno a la emancipación femenina que se desliza entre sus textos firmados y sus columnas joco-satíricas en varias publicaciones de la época, el cual habría desencadenado, según señala, la asunción de un nuevo perfil autoral más conservador por parte de Torres y Quiroga que se plasma en el seudónimo de Matilde Elena Wuili y el uso del fantástico para canalizar sus denuncias sobre las desigualdades de género y la violencia machista en la sociedad de su tiempo. 
y trasvestirse en Emma Verdier para dar rienda suelta a su pulsión sentimental. Él acuña el seudónimo y da a conocer sus primeros poemas sentimentales en la prensa, si bien Gorriti luego le inventa una biografía marcada por el melodrama sentimental (una joven enamorada, cuyo padre la encierra para impedir su amor y llevarla de vuelta a Francia), recuperando esta historia años después en Lo intimo, como una anécdota. Según relata la escritora, al solicitar a Demaría más detalles sobre aquella poeta que había llamado su atención, su amigo responde:

-Emma Verdier, ¿señora?... ¡Ah!... No sé si debo... Pero... Pues que Vd. lo pregunta, forzoso me es decirle que la tiene cerca de sí.

- ¿En la vecindad? ¡Qué dicha!

-Al lado suyo, señora.

[...]

Quedeme alelada, mirando a mi interlocutor.

-¡Cómo! -exclamé- aquellos versos de juvenil frescura donde la niña ríe corriendo entre los floridos arbustos, donde la virgen suena a la luz del crepúsculo el ideal que ha de llenar su alma, ¿todo ese dulce idilio era solo...?

-El fruto de las horas de ocio de un tabelión -repuso el señor D... con el encogimiento del niño sorprendido en una travesura-. Toda mi vida he gustado de hacer versos idílicos, grave pecado en mi profesión; pecado que hacía oculto en el más recóndito rincón de mi escritorio, bajo los terribles protocolos del litigio humano, y al lado de otros trabajos, aunque rimados serios y de alto alcance. Pero ¡ah! ¿Qué escritor no anheló siquiera una vez, loquear en las páginas de un libro? Yo tuve ese antojo, y... he ahí a Emma Verdier. Para todos, mi heroína florece en el paisaje entrerriano, esa tierra de los poetas; usted sola conoce mi secreto. (2012: 100-101)

El secreto de Demaría, con la ayuda de Gorriti, se convierte en un verdadero personaje de la escena literaria porteña, que publica en las páginas de La Ondina del Plata y es destinataria de reseñas y poemas que le dedican escritores del momento como Rafael Obligado. Narrado en tono lúdico el episodio no parece superar lo anecdótico, pero en el contexto de lo analizado a lo largo de este trabajo adquiere otra dimensión. A contrapelo de las posiciones adoptadas por Martí o Darío (incluso Palma, al procurar escapar de la melancolía que siente por el pasado perdido al negarse a prologar Veladas literarias de Lima), Demaría no rehúye su veta sentimental; por el contrario, encuentra un modo de sortear los códigos afectivos canónicos de su tiempo gracias a la libertad de juego que la prensa le ofrece en sus páginas repletas de seudónimos, sobreentendidos y chanzas.

Protegido por la supuesta frivolidad de estas publicaciones, Demaría se convierte en Emma Verdier y, con este gesto, subvierte la lógica autoral que el patriarcado había dictado a las mujeres, desestabilizando las jerarquías: ya no son ellas las que se enmascaran de hombres para poder escribir, sino que son los hombres (un hombre) quienes, gracias a la voz femenina, se permiten "loquear" por fuera de "los terribles protocolos del litigio humano" y dar rienda suelta a su sentimentalismo. En este sentido, el episodio nos permite pensar otro doblez para los juegos discursivos que habilita la prensa argentina para mujeres de finales del siglo XIX y la retórica sororal que las escritoras proponen para legitimarse en sus páginas, exponiendo hasta qué punto, en el dinamismo propio de los periódicos de la época y en su imperativo de entretener, asomaron otros deseos y códigos afectivos que jugaron e incluso fracturaron por momentos las emociones ejemplares del ángel del hogar y la domesticidad decimonónicas. 


\section{Q Bibliografía}

» Ahmed, S. (2012). The Cultural Politics of Emotion. Londres, Edinburgh Press.

"-----. (2019). La promesa de la felicidad. Una crítica cultural al imperativo de la alegría. Buenos Aires, La caja negra.

» Auza, N. T. (1988). Periodismo y Feminismo en la Argentina, 1830-1930. Buenos Aires, Emecé.

»Abraham, C. (ed.).(2012). Raimunda Torres y Quiroga: Precursora de la literatura fantástica argentina- En Torres y Quiroga, Raymunda, Historias inverosímiles. Temperley, Tren en Movimiento. págs. 9-68.

»Barrancos, D. (2007). Mujeres en la sociedad argentina: Una historia de cinco siglos. Buenos Aires, Sudamericana.

» Batticuore, G. (1999). El taller de la escritora. Veladas literarias de Juana Manuela Gorriti, Lima-Buenos Aires (1876-1877/1892). Rosario, Beatriz Viterbo.

"-----. (2005). La mujer romántica. Lectoras, autoras y escritores en la Argentina: 1830-1870. Buenos Aires, Edhasa.

"Bolufer Peruga, M. (2000). Galerías de "mujeres ilustres", o el sinuoso camino de la excepción a la norma cotidiana (ss. XV-XVIII). En Hispania: Revista Española de Historia, CSIC, vol. LX/1, núm. 204.

» Buret, F. (2017). La emergencia de la literatura fantástica argentina en revistas culturales (1861-1884). Americanismo y cosmopolitismo en los textos fantásticos de Gorriti, Wili (Torres y Quiroga), Monsalve y otros autores. Tesis de doctorado en Letras, Universidad Nacional de La Plata. Facultad de Humanidades y Ciencias de la Educación. En línea en: http://www.memoria.fahce.unlp.edu.ar/ library $? \mathrm{a}=\mathrm{d} \& \mathrm{c}=$ tesis $\& \mathrm{~d}=\mathrm{Jte} 1461$

»Carmen (1878a). “Correrías y Modas”. En El Álbum del Hogar, año 1, núm. 1, pp. $4-6,7$ de julio.

"----. 1878b). “Correrías y Modas”. En El Álbum del Hogar, año 1, núm. 3, pp. 2223, 21 de julio.

"----. (1878c). “Correrías y Modas”. En El Álbum del Hogar, año 1, núm. 7, pp. 5455,18 de agosto.

»----. (1878d). “Correrías y Modas”. En El Álbum del Hogar, año 1, núm. 9, p. 69, 1 de septiembre.

»----. (1878e). “Correrías y Modas”. En El Álbum del Hogar, año 1, núm. 23, p. 180, 8 de diciembre.

»----. (1878f). “Correrías y Modas”. En El Álbum del Hogar, año 1, núm. 27, pp. 209-910, 5 de enero.

»----. (1878g). “Correrías y Modas”. En El Álbum del Hogar, año 1, núm. 30, pp. 234-235, 26 de enero.

»----. (1878h). “Correrías y Modas”. En El Álbum del Hogar, año 1, núm. 41, pp. 321-322, 10 de abril.

"Crespo, N. (2017). Introducción. En Pelliza de Sagasta, J. La chiriguana. Buenos Aires, Teseo. 
"De Lauretis, T. (1987). Technologies of Gender. Essays on Theory, Film and Fiction. Londres, Macmillan Press.

»Denegri, F. (2004 [2006]). El abanico y la cigarrera. La primera generación de mujeres ilustradas en el Perú. Lima, Instituto de Estudio Peruanos.

» Figarilla [Josefina Pelliza de Sagasta] (1878). Mosaico. En La Alborada del Plata, año 1, núm. 18,15 de abril.

» Frederick, B. (1998). Wily Modesty. Argentine Women Writers, 1860-1910. Arizona, ASU Center for Latin American Studies Press.

» Goldgel, V. (2013). Cuando lo nuevo conquistó América. Prensa, moda y literatura en el siglo XIX. Buenos Aires, Siglo XXI.

》 Gorriti, J. M. (2012). Lo íntimo. Córdoba, Buena Vista.

» Gorriti, J. M. (1865). Sueños y realidades.

"Gorriti, J. M. (1876). Panoramas de la vida.

»Gorriti, J. M. (xxxx) Peregrinaciones de una alma triste.

»----. (2016). Veladas literarias de Lima. Buenos Aires, Eudeba.

" Hallstead, S. R. (2006). Fashion Nation: The Politics of Dress and Gender in 19th Century Argentine Journalism (1829-1880). Pittsburgh, University of Pittsburgh- En línea en: http://d-scholarship.pitt.edu/6634/

»Lancaster, B. (1995). The Department Store: A Social History. Londres, Leicester University Press.

» Masiello, F. (1994). La mujer y el espacio público. El periodismo femenino en la Argentina del siglo XIX. Buenos Aires, Feminaria.

»----. (1997). Entre civilización y barbarie. Mujeres, Nación y Cultura literaria en la Argentina moderna. Rosario, Beatriz Viterbo.

"Peluffo, A. (2005). Desencuentros de la sororidad republicana en el Perú de fin de siglo. En André, M. C. y Rubio, P. (comps.). Entre mujeres: Colaboraciones, influencias e intertextualidades en la literatura y el arte latinoamericanos. Santiago de Chile, RIL.

»----. (2016). En clave emocional. Cultura y afecto en América Latina. Buenos Aires, Prometeo.

»Peterson, L. (2009). Becoming a Woman of Letters: Myths of Authorship and Facts of the Victorian Market. Nueva York, Princeton University Press.

» Pintos, L. T. (1875a). Juana Manso. En La Ondina del Plata, año 1, núm. 13, p. 145, 2 de mayo.

»----. (1875b). La Sra. Da Juana Manuela Gorriti. En La Ondina del Plata, año 1, núm. 5, 7 de marzo.

» Román, C. (2017). Prensa, política y cultura visual. El mosquito (Buenos Aires 1863-1893). Buenos Aires, Ampersand.

"Rosenwein, B. (2006). Emotional Communities in the Early Middle Ages. Ithaca, Cornell University Press.

»Vicens, M. (2019). Por una tradición propia: genealogías y legitimación en las escritoras transhispánicas de entresiglos. En Revista de Estudios Hispánicos. Washington University in St. Louis, tomo 53, núm 1, marzo.

»Zucotti, L. P. (1998). Juana Manso: entre la pose y la palabra. En Mujeres argentinas. El lado femenino de nuestra historia. Buenos Aires, Alfaguara. 
